\title{
The Leech Haemopis lateromaculata (Hirudinea: Haemopidae): Its North America Distribution and Additional Notes on Species Description
}

\author{
PeTER Hovingh \\ 721 Second Avenue, Salt Lake City, Utah 84103 USA; e-mail: phovingh@xmission.com
}

Hovingh, Peter. 2006. The leech Haemopis lateromaculata (Hirudinea: Haemopidae): Its North American distribution and additional notes on species description. Canadian Field-Naturalist 120(4): 443-451.

The geographic range of Haemopis lateromaculata Mathers 1963 (Hirudinea: Haemopidae) is extended across North America. Its distribution in the coastal region of Alaska and British Columbia suggests a coastal Pleistocene refugia separate from the populations in the lower United States and suggests that $H$. lateromaculata and the Eurasian $H$. sanguisuga Linnaeus 1758 are sister taxa. Support of the identification and geography is based on the anatomical positions of the reproductive organs in H. lateromaculata and H. marmorata Say 1824. The variations within these species are described, noting that no specific variation was confined to a geographical region.

Key Words: leech, Haemopis laterormaculata, description, taxonomy, distribution, North America.

In an effort to understand the limits of leech (Hirudinea) fauna distribution in western North America, a geographical study defined by hydrological basins was undertaken and is still in progress. The report herein describes a taxonomic problem with Haemopis marmorata (Say 1824) in western North America, a species known to be difficult to distinguish by external characteristics from H. grandis (Verrill 1874) (Sawyer 1972) and $H$. lateromaculata. Four populations of Haemopis were found without teeth and these populations were initially identified as $H$. grandis (Hovingh 1993). Examination by dissection revealed that the penis sheaths of these populations were $H$. marmorata and that these specimens had jaws. As a result of this identification problem, the penis sheaths of all mature Haemopis were examined.

In examining the reproductive organs of Haemopis, it became apparent that $H$. lateromaculata specimens in museum collections had often been misidentified as H. marmorata. A study of Utah (Beck 1954) and Alaskan (Moore and Meyer 1951) Haemopis vouchers deposited in the United States National Museum (USNM) contained several lots identified as $H$. lateromaculata. Three lots of specimens that were collected from British Columbia and Newfoundland, two of which were identified by J. Madill as H. lateromaculata plus one unidentified due to poor conditions are deposited in The Canadian Museum of Nature (CMN) in Ottawa, Ontario, Canada. The two lots at $\mathrm{CMN}$ are the first observations of $H$. lateromaculata outside of the type localities of Minnesota and Iowa (Mathers 1963). A specimen from Michigan was utilized in a leech phylogenetic studies (Borda and Siddall 2004).

The reproductive organs of Haemopis marmorata and $H$. lateromaculata specimens collected from western North America examined are presented in this paper. Based on accurate diagnosis of the species, the external characteristics (pigmentation patterns) were determined to distinguish these two species from one another. The results herein describe the geographical distribution of $H$. lateromaculata, and support some taxonomic and paleogeographic hypotheses concerning the family Haemopidae.

\section{Methods}

Specimens of Haemopis were collected during the last 20 years from localities in western North America. The surveys consisted of visual encounters and hand picking from the underside of stones, logs, and aquatic vegetation. The specimens were relaxed with $10 \%$ ethanol, blotted by paper towel to removed the mucous excreted from the relaxation process, fixed with $10 \%$ formalin in phosphate buffered saline between two sheets of paper towels overnight, and placed in $70 \%$ ethanol for preservation.

Identification of all large Haemopis specimens was determined by examining the reproductive organs through a mid-dorsal cut from the annulus with the female gonopore posteriorly approximately 20 annuli. If the penis sheath was not located with this examination, the dorsal cut was extended anteriorly for some 10 annuli. Teeth and jaws were examined by a midventral cut of the lower lip. Posterior sucker width, pigmentation, and gonopore positions were noted. Small specimens were identified by pigmentation. Identifications followed original descriptions and taxonomic keys (Mathers 1963; Klemm 1985; Sawyer and Shelley 1976).

The facilities and specimens of the United States National Museum (USNM), Washington D.C. and the Canadian Museum of Nature (CMN), Ottawa, Ontario were utilized. The western specimens of Haemopidae in these collections were confirmed by dissection if the length was greater than $40 \mathrm{~mm}$, and pigmentation patterns and the presence of teeth were examined. The eastern specimens of Haemopis marmorata were select- 
ed by pigmentation with dissection on random samples. Specimens were also examined from water quality studies in Wyoming (Wyoming Department of Water Quality), now residing in the Albertson College of Idaho Orma J. Smith Museum of Natural History (ALBRCIDA), Boise, Idaho.

\section{Taxonomic status}

There is presently full acceptance of the haemopisine species (Davies 1991; Klemm 1985; Sawyer 1986). The higher classification of leech groupings, and leeches within the Annelida, is presently contentious, however. Historically, all the haemopisine species were placed in the genus Haemopis including the original description by Mathers $(1954,1963)$ of $H$. kingi Mathers 1954 and $H$. lateromaculata. Richardson (1969) revised the family Hirudinidae, established the family Haemopidae, and revised the genus classification by introducing the genera Percymoorensis including $P$. terrestris (Forbes 1890), P. marmorata, $P$. lateromaculata, and P. kingi), Mollibdella grandis, and Bdellarogatis plumbeus Moore 1912). He retained Haemopis for the Eurasian $H$. sanguisuga Linnaeus 1758. Richardson (1971) suggested that Percymoorensis and Haemopis (the Eurasian species) were associated in the subfamily Haemopinae, and that Mollibdella and Bdellarogatis were in the subfamily Mollibdellinae; he also identified a Mexican species Percymoorensis caballeroi Richardson 1971 in that paper.

Davies (1991); Davies and Govedich (2001); and Soós (1969) accepted the generic nomenclature of Richardson (1969) but retained the earlier familial classification of Hirudinidae. Soós (1969) expressed reservation about Richardson's classification of Hirudinidae (including Haemopidae) based on his use of type-specimens, and that "long standing genera are strongly heterogeneous in content and cannot any longer be separated one from the other entirely by single factors, or contained within single divisions in the key". Klemm (1995), Manoleli et al. (1998), and Sawyer (1986) rejected the generic nomenclatural changes of Richardson but accepted the family Haemopidae classification.

A new species, Haemopis septagon Sawyer and Shelley 1976, was described from specimens collected from North Carolina in eastern United States. In their description Sawyer and Shelley noted that if the classification of Richardson (1969) was accepted, H. septagon warranted placement in a new genus. Davies (1991) placed this species with the genus Percymoorensis. The uncertainty of Richardson's classification with respect to $H$. king $i$ and $H$. lateromaculata was revealed when Richardson $(1969,1971)$ stated that these two species most likely belong to a new genus. He did not examine either species but relied on Mathers (1954, 1963) for his paper (Richardson 1969). Borda and Siddall (2004) examined six species of Haemopis for phylogenetic studies involving anatomical characteristics, $12 \mathrm{~S}$ mitochondrial rDNA, $18 \mathrm{~S}$ and $28 \mathrm{~S}$ nuclear rDNA, and cytochrome c oxidase subunit I gene fragments. Of the 24 anatomical criteria that were utilized, 23 were common to all six species, thus not significant in determining genera or species relations. Borda and Siddall (2004) confirmed the family Haemopidae. I maintain use of the genus Haemopis and the family Haemopidae until additional and more conclusive phylogenetic studies have been reported for all the hemopisine species, using population samples representing the entire range of these widespread species.

\section{Results}

Distribution of Haemopis lateromaculata in

North America

The Nearctic distribution of Haemopis lateromaculata is shown in Figure 1 and listed in Table 1. This distribution is based on museum specimens (USNM, ALBRCIDA, and CMN), from my (PH) collections from the geographical studies in western North America and from water quality studies in Wyoming (ALBRCIDA). Anatomical dissections distinguished $H$. lateromaculata from $H$. marmorata in western North America when the plain ventrum and plain, cream, or yellow colored lateral margins were prominent, and thus could be used to distinguish these two congeners from one another. Based on this pigmentation distinction, juvenile specimens $(<40 \mathrm{~mm})$ and museum specimens in eastern North America H. marmorata, were examined and those with no ventral pigmentation were considered $H$. lateromaculata. Some specimens without pigmentation were dissected and the species determined. The following are the locations of Haemopis lateromaculata (underlined accession numbers refer to museum specimens catalogued as $H$. marmorata or as Haemopis). Most of these misidentified specimens had been catalogued and accessioned into the museum collections before the work of Mathers (1963) had been completed and published.

Alaska: USNM 19230 Yes Bay, 20732 Afognak Island, 21255 Yes Bay, 21256 Sanak Island, 43455 Revillagigedo Island, CMNA 1982-0746 Esther Island, and PH collections from Susitna River drainage, Kenai Peninsula, and Kodiak Island.

Western Canada: Yukon Territory: PH collection from Pelly River drainage (Yukon River drainage); British Columbia: USNM 19231 North Fork Moose River (at least two Moose Rivers occur in British Columbia), and USNM 38352 "D” [Dee] Lake; CMNA 1985-0289 and CMNA 1990-0056 (identified by J. Madill, but was not found in the collection) Fraser River drainage; and from $\mathrm{PH}$ collections from the Fraser River drainage (CMNA 2006-0036) and Haida Gwaii (Queen Charlotte Islands) (CMNA 2006-0037); Alberta: CMNA 1978-0426 Mackenzie River drainage; and from PH collection Peace River drainage (Mackenzie River drainage) (CMNA 2006-0034).

Lower western United States: Idaho: from PH collection in the Snake River drainage (Columbia River 


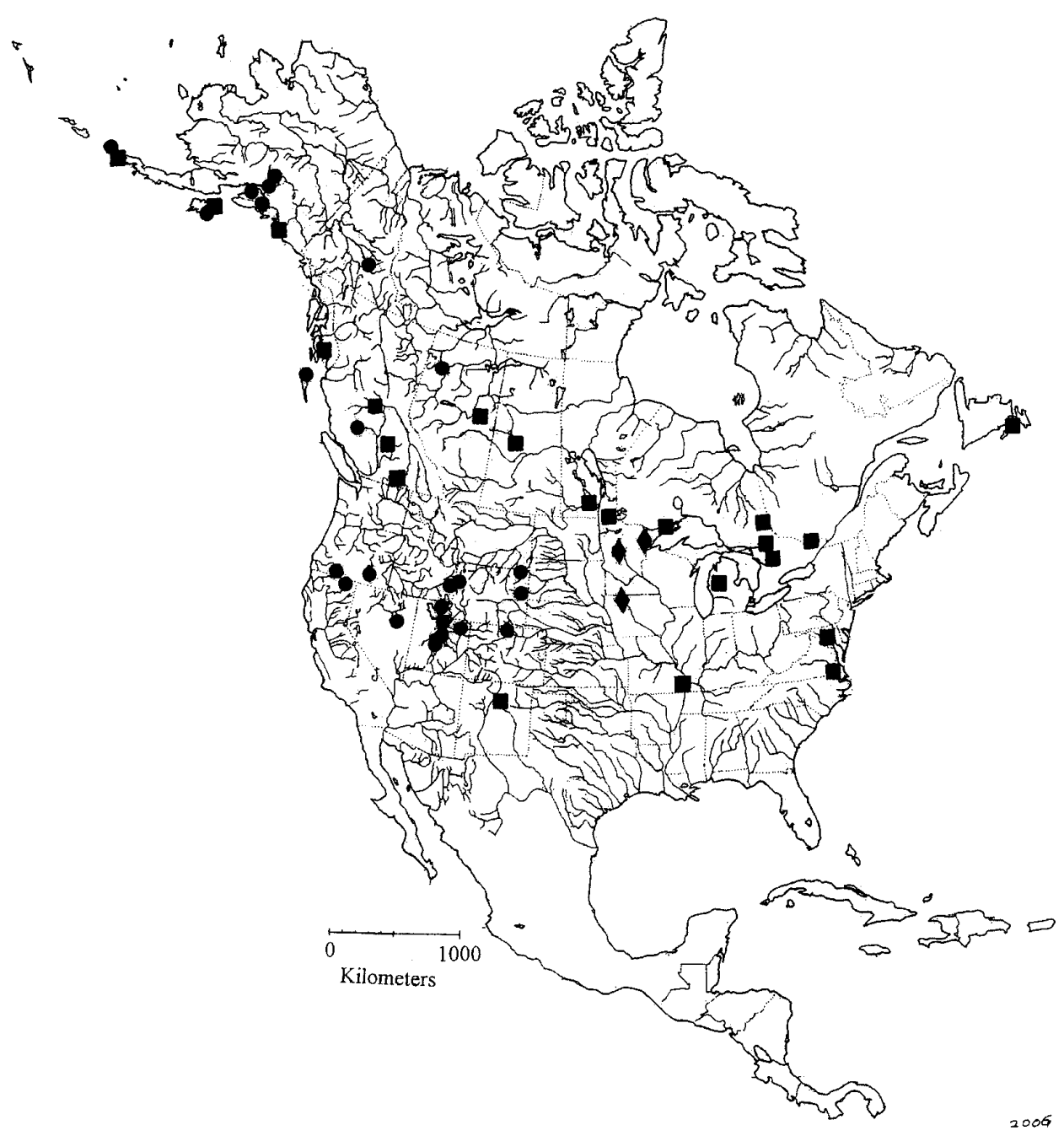

FIGURE 1. The distribution of Haemopis lateromaculata in North America. Locations are shown by (a) squares, museum specimens (NMNH, CMN); (b) circles, western North America survey sites (preliminary results) and identifications from Wyoming water quality studies; and (C) diamonds, Mathers (1963) locations.

drainage); Oregon: from $\mathrm{PH}$ collection in the Klamath River drainage and the Great Basin; Wyoming: from $\mathrm{PH}$ collection in the Snake River drainage (Columbia River drainage) and Water Quality Studies in Missouri River drainage (ALBRCIDA 61050-61052); California: from $\mathrm{PH}$ collection in the Pit River drainage (Sacramento River drainage); Nevada: from $\mathrm{PH}$ collection in the Great Basin; Utah: USNM 38308, 39056, USNM 38624,38627 (the latter two identified to genus), and from $\mathrm{PH}$ collection in the Great Basin and Colorado River drainage; Colorado: from $\mathrm{PH}$ collection in the South Platte River drainage (Missouri River drainage);
New Mexico: USNM 50192 Rio Grande drainage (did not dissect) .

Eastern North America: Canada: Saskatchewan: USNM 38353; Manitoba: USNM 38347, CMN 19850292, 1985-0301; Ontario: USNM 38360, 38348, CMN 1985-0253, 1985-259, 1985-279, 1987-0670, 1988-0036, 1988-0163; Newfoundland: CMN 19820654, 1985-0378 (both identified by J. Madill); lower United States: Michigan: USNM 38331; Missouri: USNM 20681; District of Columbia: USNM 30223; Virginia: USNM 42650. 
TABLE 1. Distribution of Haemopis lateromaculata in North America, from the field collections in western North America and from the Orma J. Smith Museum of Natural History (ALBRICIDA), Canadian Museum of Nature (CMNA), and the United States Museum of Natural History (USNM). (1) In poor condition or not found in the collection. (2) At least two Moose Rivers in British Columbia. (3) Haemopis unidentified. PH, Peter Hovingh collection work in progress.

\begin{tabular}{|c|c|c|c|}
\hline Province or State & Catalogue & Date & Locator \\
\hline Alberta & CMNA 1978-0426 & 1907 & Beaver Lake \\
\hline Alberta & CMNA 2006-0034 & 2000 & Slave River drainage \\
\hline British Columbia & CMNA 1985-0289 & 1976 & 150 Mile House \\
\hline British Columbia & CMNA 1990-0056 & 1989 & Cariboo District \\
\hline British Columbia & CMNA 2006-0036 & 1988 & Chilcotin River drainage(1) \\
\hline British Columbia & CMNA 2006-0037 & 2000 & Haida Gwaii \\
\hline British Columbia & USNM 19231 & 1911 & North Fork Moose River (2) \\
\hline British Columbia & USNM 38352 & 1935 & [Dee] "D" Lake \\
\hline Manitoba & CMNA 1985-0301 & 1970 & Vita \\
\hline Manitoba & CMNA 1985-0292 & 1976 & LaSalle River \\
\hline Manitoba & USNM 38347 & 1927 & \\
\hline Newfoundland & CMNA 1982-0654 & 1981 & Placenta Bay \\
\hline Newfoundland & CMNA 1985-0378 & 1985 & St Marys Bay \\
\hline Ontario & CMNA 1985-0259 & 1920 & Abitibi River \\
\hline Ontario & CMNA 1985-0262 & 1920 & Missinaibi River \\
\hline Ontario & CMNA 1985-0253 & 1922 & Ottawa River \\
\hline Ontario & CMNA 1985-0279 & 1965 & Albany River \\
\hline Ontario & CMNA 1988-0036 & 1987 & Thunder Bay \\
\hline Ontario & CMNA 1988-0163 & 1987 & Rainy River \\
\hline Ontario & CMNA $1987-0670$ & 1987 & Kenora \\
\hline Ontario & USNM 38348 & 1925 & Lake Abitibi \\
\hline Ontario & USNM 38360 & 1931 & Lake Nipissing \\
\hline Saskatchewan & USNM 38353 & 1940 & Waskasov \\
\hline Yukon Territory & CMNA 2006-0035 & 2000 & Pelly River drainage \\
\hline Alaska & CMNA1982-0746 & 1961 & Esther Island \\
\hline Alaska & CMNA 1985-0297 & 1961 & Hinchinbrook Island (3) \\
\hline Alaska & CMNA 1978-0360 & 1961 & Chuckagof Island (3) \\
\hline Alaska & USNM 19230 & 1905 & Lake Mc Donald, Yes Bay \\
\hline Alaska & USNM 21225 & 1907 & Lake Mc Donald, Yes Bay \\
\hline Alaska & USNM 20732 & 1938 & Afognak Island \\
\hline Alaska & USNM 21256 & 1937 & Sanak Island \\
\hline Alaska & USNM 43455 & 1897 & Revillagigedo Island \\
\hline Alaska & PH $1671-1677$ & 2003 & Kodiak Island \\
\hline Alaska & PH 1660 & 1994 & Cook Inlet \\
\hline Alaska & PH 1661-1664 & 2003 & Cook Inlet \\
\hline Alaska & PH 1667,1669 & 1994 & Kenai Peninsula \\
\hline Alaska & PH 1665,1666 & 2003 & Kenai Peninsula \\
\hline Alaska & PH 1668,1669 & 2003 & Kenai Peninsula \\
\hline Alaska & PH 2029 & 2006 & Cold Bay, Alaska Peninsula \\
\hline California & PH $(0000)$ & & Pit River \\
\hline Colorado & $\mathrm{PH}(0000)$ & 2002 & Great Plains \\
\hline District of Columbia & USNM 30223 & 1911 & Easter Branch \\
\hline Idaho & $\mathrm{PH}(0000)$ & 1994 & Snake River drainage \\
\hline Michigan & USNM 38331 & 1925 & Mecosta County \\
\hline Missouri & USNM 20681 & 1935 & Sikeston \\
\hline Nevada & USNM (PH 848) & 1989 & Ruby Marsh \\
\hline New Mexico & USNM 50192 & 1929 & Pecos River \\
\hline Oregon & USNM (PH 852) & 1996 & Catlow Valley \\
\hline Oregon & PH $(0000)$ & 1995 & Klamath Lake \\
\hline Utah & USNM 38308 & 1952 & Provo \\
\hline Utah & USNM 38624 & 1952 & \\
\hline Utah & USNM 38627 & 1952 & Mapleton \\
\hline Utah & USNM 39056 & 1952 & Provo \\
\hline Utah & USNM (PH 497) & 1990 & Provo River \\
\hline Utah & USNM (PH 498) & 1995 & Provo River \\
\hline Utah & USNM (PH 499) & 1989 & Provo River \\
\hline Utah & USNM (PH 489) & 1989 & Sevier River \\
\hline Utah & USNM (PH 491) & 1995 & Sevier River \\
\hline Utah & USNM (PH 487) & 1990 & Weber River \\
\hline Utah & USNM (PH 488) & 1994 & Weber River \\
\hline Utah & USNM (PH 486) & 1993 & Bear River \\
\hline
\end{tabular}


TABLE 1. continued

\begin{tabular}{llll}
\hline \hline Province or State & Catalogue & Date & Locator \\
\hline Virginia & USNM 42650 & 1957 & Dismal Swamp \\
Wyoming & PH (0000) & 1991 & Snake River drainage \\
Wyoming & ALBRICIDA 61050 & 1994 & Johnson County \\
Wyoming & ALBRICIDA 61051 & 1997 & Crook County \\
Wyoming & ALBRICIDA 61052 & 1997 & Niobrara County \\
\hline \hline
\end{tabular}

Identification of leech specimens: external characteristics

TEETH. All of the Haemopis lateromaculata contained teeth (denticles). This characteristic would separate these specimens from $H$. plumbea and $H$. grandis. Four populations (Utah, Nevada, Wyoming, Montana) of $H$. marmorata were without teeth. One population (Utah) was collected in 1941 (USNM 50195) and again in 1986 suggesting that the loss of denticles may be due to environmental or genetic factors resulting from colonization after the dessication of Lake Bonneville after 13000 years ago.

POSTERIOR SUCKER. Although the posterior sucker is large (about $3 / 4$ the width of the body) in Haemopis lateromaculata and small (less than $1 / 2$ the width of the body) in $H$. marmorata (Klemm 1985), the state of body relaxation was highly variable. This variability made the relative size of the posterior sucker to body width rather arbitrary.

Pigmentation. The dorsal surface of Haemopis lateromaculata was patterned with darker blotches or mottled, or large to small speckles, of frequent to rare numbers. The lateral margins were cream or yellow (shared with $H$. terrestris) and interrupted with irregular dark intrusions dorsally (a very diagnostic character), visible from both the dorsal and ventral surface [specimens from 14 sites: the Great Basin (8), Colorado River drainage (2), Great Plains (1), Columbia River drainage (2), and the Yukon River drainage (1)]; or with the lateral margins the same shade as the ventrum, without cream or yellow coloring [specimens from 21 sites: the Great Basin (2), Pacific Coast drainages (2), Fraser River drainage (1), Mackenzie River drainage (1), coastal islands and their adjacent shores of British Columbia and Alaska (17)]. The external characteristic that identified all of the specimens was the plain ventral surface. Mathers (1963: page 170) noted "with a few indistinct black and yellow blotches" on the ventral surface. I observed one specimen with an occasional speckle on the ventral surface.

The pigmentation of $H$. marmorata in western North America ranged from heavily blotched or mottled to heavily speckled or lightly speckled on both the dorsum and ventrum (61 sites), with the ventrum having subdued pigmentation of the same pattern. If either $H$. lateromaculata or H. marmorata were of the light- and/ or dark-colored immaculate phase (Klemm 1985: page $155)$, pigmentation could not be used to identify these two species. The light-colored immaculate phase was not found in the living state in western North America, but only in preserved specimens in museums. The lack of a dorsal stripe excluded $H$. terrestris, $H$. kingi, and $H$. septagon from further consideration in this study.

MAXIMUM LENGTH (MM). Haemopis lateromaculata: Great Basin (90), Colorado River drainage (67), Columbia River drainagae (31), Mackenzie River drainage (83), Fraser River drainage (30), Queen Charlotte Islands (81), Yukon River drainage (82), Alaska (112), and Great Plains (50). Haemopis marmorata: Great Basin (112), Colorado River drainage (95), Columbia River drainage (121), Pacific Coast drainages (98), Fraser River drainage (98), and Great Plains (94). Length is highly variable, dependent upon both the age of living specimens and their state of relaxation during fixation.

GONOPORE POSITIONS. Haemopis lateromaculata: Male gonopore XI $b 6$ anterior $1 / 3$; female gonopore XII b6 anterior $1 / 3$, as determined on two specimens with developed clitellum from Nevada and Yukon Territory. All gonopore positions were separated by 5 annuli and occurred on the anterior $1 / 3$ of the annulus. Haemopis marmorata: Male gonopore XI $b 6$ anterior $1 / 3$; female gonopore XII $b 6$ anterior $1 / 3$, as determined on three specimens with developed clitellum from Nevada and Colorado. Most gonopore positions were separated by 5 annuli and occurred on the anterior $1 / 3$ of the annulus. Three exceptions: male XI $b 6$ mid-annulus and female XII $b 6$ mid-annulus, and male XI $b 6$ mid-annulus and female XII $b 5$ posterior $1 / 3$ both from Arizona; and male and female on mid-annulus from British Columbia. Sawyer (1972) noted additional variations of the gonopores from mid-annulus to the furrow. The male and female gonopore separations excluded $H$. septagon from further consideration during this study.

Identification of leech specimens by reproductive organs

Figure 2 illustrates the mean measurements of the reproductive organ position and Table 2 lists the mean \pm standard deviation. The posterior position of the left and right ejaculatory bulbs, the posterior position of the penis sheath loop and the vagina organs, and the anterior position of the prostate organ (anterior end of male atrium) were selected for their defined shape, largely attributed to the muscular nature of the organs (Richardson 1969). The organ positions were determined by vertical positioning of the organ with the annulus, and hence counting the number of annuli to the annulus with the female gonopore. There is a possible error of annuli count of \pm 1 annulus due to the positioning in individual specimens. The nomenclature of the organs follows that of Klemm (1985). Left and right positions are determined from the dorsal side. Comparison to 
other species is based on literature (Klemm 1985; Mann 1954; Richardson 1971).

PENIS SHEATH LOOP. Haemopis lateromaculata: The penis sheath loop was located at annulus XIII $b 5$ (XII $b 6$ to XIV $a 2$ ). The penis sheath was generally Ushaped and distinguished $H$. lateromaculata from $H$. marmorata, $H$. plumbea, $H$. terrestris, $H$. septagon, and $H$. caballeroi. Haemopis marmorata: The penis sheath loop was located at annulus XVII $b 1$ (XVbl to XVIII $b 5$ ), a range comparable to Sawyer (1972). The penis sheath was generally J-shaped and on the left side. The ranges did not overlap between $H$. lateromaculat $a$ and $H$. marmorata. The average length of the penis sheath of $H$. lateromaculata was 21 annuli and of $H$. marmorata 38 annuli between the male gonopore and the prostate gland. Abnormal variations for the penis sheath of $H$. lateromaculata include position on the right side (4 specimens from Yukon Territory, Alaska, and Colorado) and highly contorted (1 specimen from Alaska). Abnormal variations for the penis sheath of H. marmorata include: positioned on the right side (11 specimens from Great Basin, Colorado River Basin, and Great Plains), and highly contorted (6 specimens from Great Basin, Great Plains) with one specimen in which the terminal loop turns medially and is twisted to form a topless " 8 ".

PROSTATE GLAND. Haemopis lateromaculata: The anterior end of the male atrium is covered by the prostate gland and was located at annulus XI $a 2$ (X $a 2$ to XII $b 6$ ), positions that are anterior to the female gonopore and for the most part anterior to the male gonopore. These locations are associated with the U-shaped penis sheath. Haemopis marmorata: The anterior end of the prostate gland was located at annulus XIV $b 5$ (XIII $b 1$ to XVI $b 5$ ), defining the J-shaped penis sheath.

EJACULATORY BULBS. Haemopis lateromaculata: The posterior end of the left ejaculatory bulb (seminal vesicle) was located at annulus XIII $b 2$ (XII $b 2$ to XIV $a 2)$ whereas the posterior end of the right ejaculatory bulb was at annulus XIII $b 1$ (XII $b 1$ to XIV $a 2$ ). Although the locations show left-right symmetry (Figure 2), large variations were found in which the left bulb was 10 annuli posterior to 7 annuli anterior of the right bulb. The distribution of the positions of the ejaculatory bulbs was: right anterior to the left, 13 specimens; right even with the left, 13 specimens; and right posterior to the left, 8 specimens). Haemopis marmorata: The posterior end of the left ejaculatory bulb was located at XIV b2 (XIII $b 1$ to XV b5) whereas the posterior end of the right ejaculatory bulb was at annulus XIV $b 1$ (XII $a 2$ to XV $b 6$ ). The left bulb ranged from 9 annuli posterior to 5 annuli anterior of the right bulb. The distribution of the ejaculatory bulbs was: right anterior to the left, 19 specimens; right even with the left, 16 specimens; and right posterior to the left, 17 specimens), a pattern noted by Sawyer (1972). Two specimens had only one ejaculatory bulb.

VAGINA. Haemopis lateromaculata: The posterior end of the vagina (vaginal bulb) was found at XIV b6 (XIII $a 2$ to XVII $a 2$ ). The vagina was always posterior to the posterior reach of the penis sheath loop and was generally in the median region. Haemopis marmorata: the posterior end of the vagina was found at XVI $b 1$ (XIV $b 2$ to XVII $a 2$ ), comparable to the findings of Sawyer (1972). The vagina was always anterior to the posterior reach of the penis sheath loop and posterior to the anterior end of the prostate gland, and generally located in the medial region. Three specimens had the vagina location anterior to the anterior end of the prostate gland. The position of the vagina of $H$. caballeroi had a relative position to the penis sheath loop and the prostate gland (atrium) as in $\mathrm{H}$. marmorata, but the two specimens of $H$. caballeroi were highly contracted and hence not typical (Richardson 1971). The extensive penis sheath and its relation to the vagina suggests that these two species deserve a separate genus - in

TABLE 2. Annuli location of selected reproductive organs in Haemopis marmorata and H. lateromaculata. Annulus X b1 was number 1 and annuli posterior to this annulus were sequentially numbered. Organ nomenclature was taken from Klemm (1985). Figure 2 illustrates the organs and the points of measurement.

\begin{tabular}{lcc}
\hline \hline & $\begin{array}{c}\text { H. lateromaculata } \\
\mathrm{N}=31\end{array}$ & $\begin{array}{c}\text { H. marmorata } \\
\mathrm{N}=55\end{array}$ \\
\hline Penis sheath loop & & \\
Mean \pm standard deviation & $18.8 \pm 2.6$ & $35.8 \pm 4.6$ \\
Range & $14-23$ & $25-44$ \\
Anterior prostate gland & $7.2 \pm 2.5$ & $23.9 \pm 3.7$ \\
Mean \pm standard deviation & $2-14$ & $16-35$ \\
Range & & \\
Posterior left ejaculatory bulb & $16.7 \pm 3.0$ & $21.3 \pm 3.4$ \\
Mean \pm standard deviation & $11-23$ & $15-29$ \\
Range & $15.5 \pm 3.1$ & $21.0 \pm 3.4$ \\
Posterior right ejaculatory bulb & $10-23$ & $12-30$ \\
Mean \pm standard deviation & & $30.5 \pm 3.7$ \\
Range & $24.6 \pm 4.7$ & $21-38$ \\
Posterior vagina & $17-38$ & \\
Mean \pm standard deviation & & \\
Range & & \\
\hline \hline
\end{tabular}



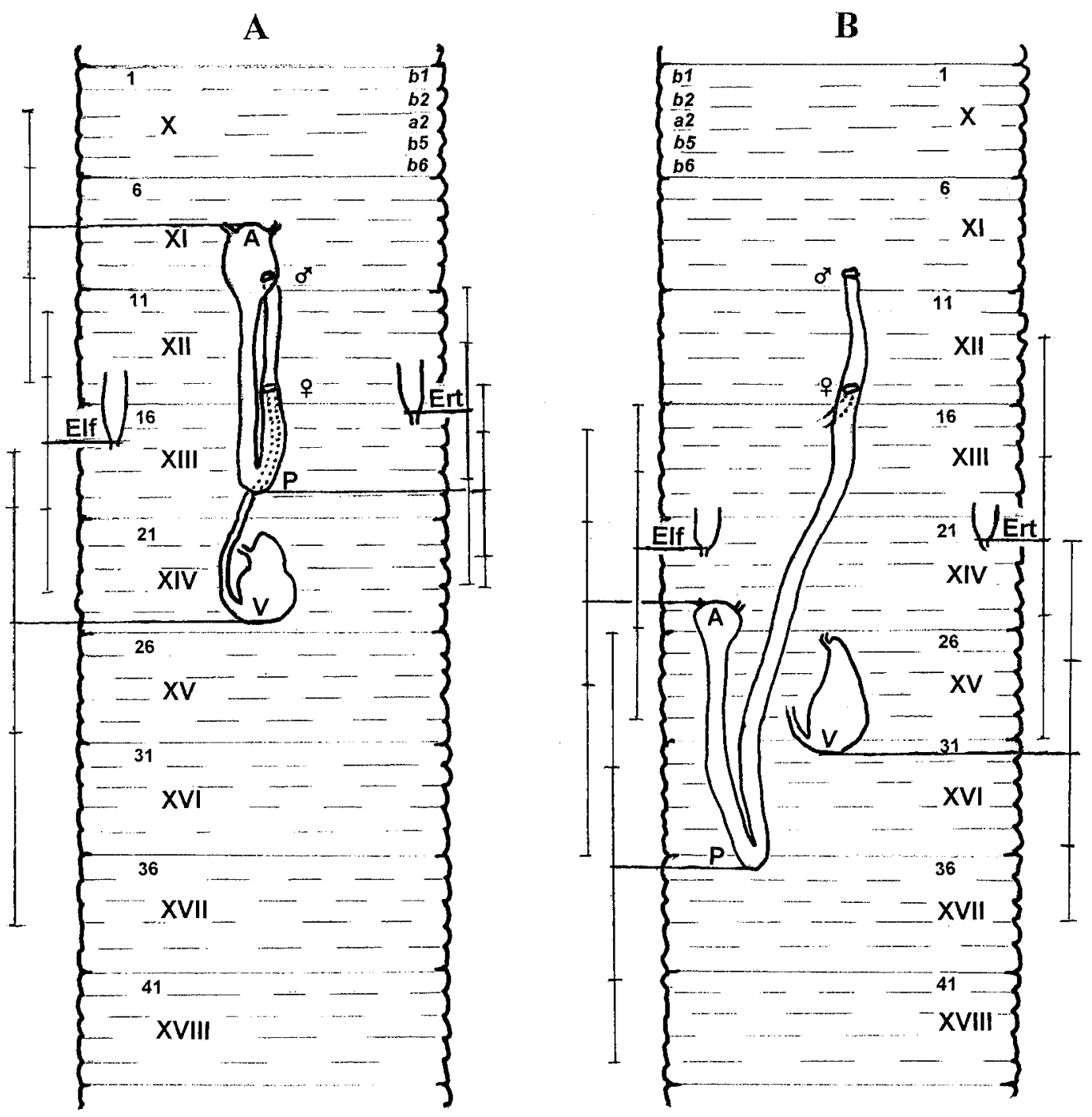

FIGURE 2. Measured reproductive organs in Haemopis lateromaculata (A) and H. marmorata (B), viewed from the dorsum. The segments are shown in Roman numerals starting with segment X and extend to segment XVIII. Each segment has five annuli as denotated names shown on the right side of segment X. For the purposes of this paper, the first annulus is numbered 1 and is sequenced posteriorly as noted on the left side with only the first annulus of each segment numbered (see Table 2). Male gonopore on IX $b 6$ and female gonopore on XII $b 6$. Denotations: Elf, posterior reach of the left ejaculatory bulb; Ert, posterior reach of the right ejaculatory bulb; P, posterior reach of the penis sheath loop; V, posterior reach of the vagina; and A, the prostate gland at the anterior end of the male atrium. The vertical lines represent one standard deviation (thick lines) and total range (thin lines) (see Table 2).

this case Percymoorensis, if one follows the distinct genera classification in Erpobdellidae of Nephelopsis, Mooreobdella, and Erpobdella, each having morphological distinct male atriums and sperm ducts.

\section{Discussion}

Haemopis lateromaculata is now considered to be widely distributed throughout North America; prior to this study, its known distribution had been limited to two states (Figure 1). The presence of this leech on the Alaskan Peninsula and adjacent islands, the Cook Inlet region, the Alexander Archipelago of southeast Alaska, and Haida Gwaii (Queen Charlotte Islands) of British Columbia suggest that these leeches occupied off-shore coastal refugia during the Pleistocene and were separated from those populations south of Canada's cordil- 
leran and continental glaciers. These northwest refugia were limited by extensive glaciers from Haida Gwaii to Umnak Islands (Coulter et al. 1965; Clague 1989; Kaufman and Manley 2004) with coastal cordilleran glaciers occurring to 12000 years ago (Peltier 1994; Dyke 2004; Fulton et al. 2004). While the occurrence of small terrestrial refugia have been postulated from Kodiak to the Queen Charlotte Islands (Heusser 1989; Ramsey et al. 2004), present day freshwater habitats (ponds, lakes, slow moving and meandering streams) from which leeches have been collected add a new dimension to the terrestrial refugia.

The Pleistocene-Holocene environments were changing due to eustasy (the sea level rising at least $120 \mathrm{~m}$ ) and glacio-isostatic surface adjustments involving the advance and recession of the glaciers. Hetherington et al. $(2003,2004)$ mapped this environment for the Haida Gwaii and described a land bridge between the islands and the British Columbia mainland that existed between 11700 and 11200 years ago as a result of the presence of a forebulge from the retreating cordilleran glacier. This process, if applied throughout the glaciated region of coastal Alaska, may have allowed island by island transfer of leeches from coastal Pleistocene refugia, thus accounting for the modern day presence of $H$. lateromaculata populations on the coastal northwestern North America mainland (Reimchen and Byun 2005). Upstream movement of $H$. marmorata has been noted (Herrmann 1970; Richardson 1942; Sawyer 1970), and active movement (to Prince Edward Island) must have occurred by direct means, and not as passive movement by birds or other agents (Richardson 1943). It is assumed herein the cordilleran glaciers and marine habitats prevented any leeches from continental populations colonizing the coastal habitats.

Lukin (1976) suggested that Haemopis originated in the Nearctic and penetrated the Palaearctic from the northeast [Siberia] when northern Asia had a warmer climate. He further suggested that $H$. sanguisuga emerged at that time and is now found across central Eurasia to the Amur Basin and near Vladivostok in eastern Asia, but not in Kamchatka Peninsula. The center of biodiversity of Haemopis is in eastern North America, supporting Lukin's postulate. Only two species $(H$. lateromaculata and $H$. marmorata) moved out of this region to occupy most of North America, and only $H$. lateromaculata has been identified in Alaska and the coastal islands, suggesting range expansion in an earlier epoch before the range expansion of $H$. marmorata. From the Late Cretaceous ( 80 million years ago) to the middle Pliocene (3 million years ago), North America and eastern Asia were connected between Alaska and eastern Siberia (Repenning and Brouwers 1992; Smith et al. 1994). For much of this time, the climate in this region was comparable to that of the southeastern United States today (Bassinger 1991).

I propose that $H$. lateromaculata and $H$. sanguisuga are sister species. Two anatomical features of $H$. lat- eromaculata and $H$. sanguisuga support this relationship: (1) the vaginal bulb lies posterior to the penis sheath loop (shared with $H$. grandis and $H$. kingi) and (2) the prostate gland (anterior end of the male atrium) occurs mostly anterior to the male gonopore (shared with $H$. kingi and $H$. caeca) (Mann 1954; Klemm 1985; Manoleli et al. 1998). Note that $H$. kingi occurs in both groups, a confirmation of Richardson's (1969, 1971) views that $H$. kingi and $H$. lateromaculata are closely related.

The distribution of a species is as important as the original description of a species. As noted by Newton (2003: page 90) with respect to birds, "how species are formed is central to understanding their distributions" and "genealogy and distribution are not separate issues: they are simply different sides of the same biological coin". This paper contributes to the definition of $H$. lateromaculata by the addition of geographical limits of its distribution and its evolutionary implications.

\section{Acknowledgments}

I thank Jacqueline Madill and Jean-Marc Gagnon at the Canadian Museum of Nature, Bill Moser at United States National Museum (Smithsonian Institution), and John Keebaugh at the Orma J. Smith Museum of Natural History for assistance and for providing facilities at these museums which greatly contributed to this study; Robert Wisseman (Aquatic Biology Associates) and Kurt King (Wyoming Department of Environmental Quality) for furnishing leeches for identification from western United States. Early versions of this document were reviewed by Bill Moser and Donald Klemm, and Jacqueline Madill and Mark J. Wetzel reviewed the manuscript for the journal. I thank these reviewers for their suggesting and improvements.

\section{Literature Cited}

Bassinger, J. F. 1991. The fossil forests of the Buchanan Lake Formation (early Tertiary), Axel Heiberg Island, Canadian Arctic Archipelago: preliminary floristics and paleoclimate. Pages 39-65 in Tertiary Fossil Forests of the Geodetic Hills, Axel Heiberg Island, Arctic Archipelago. Edited by R. L. Christie and N. J. Macmillan. Geological Survey of Canada Bulletin 403.

Beck, D. E. 1954. Ecological and distributional notes on some Utah Hirudinea. Proceedings of the Utah Academy of Science, Arts, and Letters 31: 73-78.

Borda, E., and M. E. Siddall. 2004. Arhynchobdellida (Annelida: Oligochaeta: Hirudinida): phylogenetic relationships and evolution. Molecular Phylogenetics and Evolution 30: 213-225.

Clague, J. J. 1989. Quaternary geology of the Queen Charlotte Islands. Pages 65-74 in The Outer Shores. Edited by G. G. E. Scudder and N. Gessler. Queen Charlotte Islands Museum Press, Skidegate, British Columbia.

Coulter, H. W., D. M. Hopkins, T. M. V. Karlstrom, T. L. Péwé, C. Wahrhaftig, and J. R. Williams. 1965. Map showing extent of glaciations in Alaska. Compiled by the Alaska Glacial Map Committee of the U.S. Geological Survey. U.S. Geological Survey Miscellaneous Geologic Investigations Map I-415. 
Davies, R. W. 1991. Annelida: Leeches, Polychaetes, and Acanthobdellids. Pages 437-479 in Ecology and Classification of North American Freshwater Invertebrates. Edited by J. H. Thorp and A. P. Covich. Academic Press, New York.

Davies, R. W., and F. R. Govedich. 2001. Annelida: Euhirudinea and Acanthobdellidae. Pages 465-504 in Ecology and Classification of North American Freshwater Invertebrates. Second Edition. Edited by J. H. Thorp and A. P. Covich. Academic Press, New York.

Dyke, A. S. 2004. An outline of North American deglaciation with emphasis on central and northern Canada. Pages 373424 in Quaternary Glaciation - Extent and Chronology, Part II. Edited by J. Ehlers and P. L. Gibbard. Elsevier B. V. Amsterdam.

Fulton, R. J., J. M. Ryder, and S. Tsang. 2004. The Quaternary glacial record of British Columbia, Canada. Pages 39-50 in Quaternary Glaciation- Extent and Chronology, Part II. Edited by J. Ehlers and P. L. Gibbard. Elsevier B. V. Amsterdam.

Herrmann, S. J. 1970. Systematics, distribution, and ecology of Colorado Hirudinea. American Midland Naturalist 83: $1-37$.

Hetherington, R., J. V. Barrie, R. G. B. Reid, R. MacLeod, D. J. Smith, T. S. James, and R. Kung. 2003. Late Pleistocene coastal paleogeography of Queen Charlotte Islands, British Columbia, Canada, and its implications for terrestrial biogeography and early postglacial human occupations. Canadian Journal of Earth Sciences 40: 1755-1766.

Hetherington, R., J. V. Barrie, R. G. B. Reid, R. Macleod, and D. J. Smith. 2004. Paleogeography, glacially induced crustal displacement, and Late Quaternary coastlines on the continental shelf of British Columbia, Canada. Quaternary Science Reviews 23: 295-318.

Heusser, C. J. 1989. North Pacific coastal refugia - the Queen Charlotte Islands in perspective. Pages 91-106 in The Outer Shores. Edited by G. G. E. Scudder and N. Gessler. Queen Charlotte Islands Museum Press, Skidegate, British Columbia.

Hovingh, P. 1993. Zoogeography and paleozoology of leeches, molluscs and amphibians in western Bonneville Basin, Utah, USA. Journal of Paleolimnology 9: 41-54.

Kaufman, D. S., and W. F. Manley. 2004. Pleistocene maximum and Late Wisconsinan glacier extents across Alaska, USA. Pages 9-27 in Quaternary Glaciation - Extent and Chronology, Part II. Edited by J. Ehlers and P. L. Gibbard. Elsevier B. V. Amsterdam.

Klemm, D. J. 1985. Freshwater Leeches (Annelida: Hirudinea). Pages 70-198 in A Guide to the Freshwater Annelida (Polychaeta, Naidid and Tubificid Oligochaeta, and Hirudinea) of North America. Edited by D. J. Klemm. Kendall/ Hunt Publishing Company, Dubuque, Iowa.

Klemm, D. J. 1995. Identification Guide to the Freshwater Leeches (Annelida: Hirudinea) of Florida and other southern states. Bureau of Surface Water Management, Florida Department of Environmental Protection, Tallahassee. 82 pages.

Lukin, E. I. 1976. Leeches of Fresh and Brackish Water Bodies (English translation by the Canada Museum of Nature, Ottawa). Academy of Science of the USSR Zoological Institute. "Nauka" Publishers, Leningrad. 484 pages.

Mann, K. H. 1954. The anatomy of the horse leech, Haemopis sanguisuga (L.) with particular reference to the excretory system. Zoological Society of London Proceedings 124: 69-88.
Manoleli, D. G., D. J. Klemm, and S. M. Sarbu. 1998. Haemopis caeca (Annelida: Hirudinea: Arhynchobdellida: Haemopidae), a new species of troglobitic leech from a chemoautotrophically based groundwater ecosystem in Romania. Proceedings of the Biological Society of Washington 111: 222-229.

Mathers, C. K. 1954. Haemopis kingi, new species (Annelida, Hirudinea). The American Midland Naturalist 52: 460-468.

Mathers, C. K. 1963. Haemopis latero-maculatum, New Species (Annelida, Hirudinea). The American Midland Naturalist 70: 168-174.

Moore, J. P., and M. C. Meyer. 1951. Leeches (Hirudinea) from Alaska and adjacent waters. The Wasmann Journal of Biology 9: 11-77.

Newton, I. 2003. The Speciation and Biogeography of Birds. Academic Press, London. 668 pages.

Peltier, W. R. 1994. Ice age paleotopography. Science 265: 195-201.

Ramsey, C. L., P. A. Griffiths, D. W. Fedje, R. J. Wigen, and Q. Mackie. 2004. Preliminary investigation of a late Wisconsinan fauna from K1 Cave, Queen Charlotte Islands (Haida Gwaii), Canada. Quaternary Research 62: 105-109.

Reimchen, T., and A. Byun. 2005. The evolution of endemic species in Haida Gwaii. Pages 77-95 in Haida Gwaii: human history and environment from the Time of Loon to the Time of the Iron People. Edited by D. W. Fedje and R. W. Mathewes. University of British Columbia Press, Vancouver.

Repenning, C. A., and E. M. Brouwers. 1992. Late PlioceneEarly Pleistocene Ecologic Changes in the Arctic Ocean Borderland. U.S. Geological Survey Bulletin 2036.

Richardson, L. R. 1942 Observations on the migratory behavior of leeches. Canadian Field-Naturalist 56: 67-78.

Richardson, L. R. 1943. The freshwater leeches of Prince Edward Island and the problem of the distribution of leeches. Canadian Field-Naturalist 57: 89-91.

Richardson, L. R. 1969. A contribution to the systematics of the hirudinid leeches, with description of new families, genera and species. Acta Zoologica Academiae Scientiarum Hungaricae 15: 97-149.

Richardson, L. R. 1971. A new species from Mexico of the Nearctic genus Percymoorensis, and remarks on the family Haemopidae (Hirudinoidea). Canadian Journal of Zoology 49: 1095-1103.

Sawyer, R. T. 1970. Observations on natural history and behavior of Erpobdella punctata (Leidy) (Annelida: Hirudinea). American Midland Naturalist 183: 65-80.

Sawyer, R. T. 1972. North American Freshwater Leeches, Exclusive of the Piscicolidae, with a Key to All Species. Illinois Biological Monographs 46, University of Illinois Press, Urbana. 154 pages.

Sawyer, R. T. 1986. Leech Biology and Behavior. Clarendon Press, Oxford. 1065 pages. Three volume set.

Sawyer, R. T., and R. M. Shelley. 1976. New records and species of leeches (Annelida: Hirudinea) from North and South Carolina. Journal of Natural History 10: 65-97.

Smith, A. G., D. G. Smith, and B. M. Funnell. 1994. Atlas of Mesozoic and Cenozoic Coastlines. Cambridge University Press, Cambridge. 99 pages.

Soós, Á. 1969. Identification key to the leech (Hirudinoidea) genera of the world, with a catalogue of the species. V. Family: Hirudinidae. Acta Zoologica Academiae Scientiarum Hungaricae 15: 151-201.

Received 17 January 2006

Accepted 21 April 2007 